\title{
Publication Tendency of Turkish Geography Journals*
}

\author{
Çağrı ÖZTÜRK DEMİRBAȘ 1 \\ Ahi Evran University, Kırşehir, TURKEY
}

\begin{abstract}
*This study was presented at the 1st International Geography Education Congress held at Nevşehir University on 8-10 November 2018, Nevşehir, Turkey.

${ }^{1}$ Assoc. Prof,. Department of Social Science and Turkish Education, Kırsehir Ahi Evran University Education Faculty, Kirsehir, Turkey. cagri-79 [at] hotmail.com, ORCID: 0000-0001-8719-4167
\end{abstract}

\begin{abstract}
The refereed and periodical journals, which form the basis of scientific communication, have different functions such as quality control, archival creation, the promotion of authors, and information distribution. Journals that previously addressed wider audiences and disciplines are becoming increasingly thematic today and are beginning to address a particular area of focus. Therefore, this study aims to reveal the publication policies of academic journals in Turkey which are categorized under the theme of Geography. For this purpose, academic Geography journals published in Turkey have been analyzed using a content analysis method. Also, a bibliometric analysis process has been applied to academics who publish in these journals and use the keywords geography education in their work as revealed by an academic search in Higher Education Council (referred to as YÖK in Turkish). A Journal Review Form was used to analyze data from the study, which included seven journals. From this form, the aim, scope, index, frequency of publication, type of publication, and temporal change of journals can be determined and the general trends for these journals ascertained. As a result of the research, it is determined that six journals have been published over 20 years, albeit with interruptions, while one journal was in its 9th year of publication.
\end{abstract}

\section{Keywords}

Geography Journals, Turkish Geography Journals, Geography Educators, Journal Publication Tendency,

Bibliometric Analysis 

The actions taken by scientists to present their results orally or in writing using scientific research methods are called scientific communication. As the prerequisites for continuing science, knowledge shared in scientific communication is based on previous knowledge, books, periodical refereed (or peer-reviewed) journals, and oral or poster papers presented at congresses. In this kind of communication, it is not a mistake to suggest that scientific communication is a process, considering that old knowledge is a building block used continuously to construct new knowledge.

Today, books, peer-reviewed periodicals, oral or poster papers form an avenue for scientific communication, although in the past, much narrower spaces existed for the sharing and spreading of scientific knowledge. When it is first said that people who think about the same issues in the historical process share the information they have reached orally in meetings, held under the supervision of socalled noble individuals, they also influence the identity created in academic peerreviewed journals as well as the nature of scientific knowledge. When a journal's identity is mentioned, the publication process comes to mind about how many years of continuous publication has occurred for the journal, together with its indices, received citations, and factor loads calculated on these citations.

Köksoy (1999, p. 9) uses an analogy to emphasize the importance of scientific journals: "Whatever the blood circulation system for a living thing is, scientific journals function similarly for education/training and scientific research in higher education." While the emphasis is placed on continuity and the sharing of scientific knowledge for the continuity of science, its transfer with genetic codes indicates archiving the information. Refereed journals, which are one of the tools of scientific communication, provide the opportunity to disseminate the information reached through scientific means on the one hand, and to transfer the scientific information to the next generations on the other hand (Rousseau, 2002, p. 419). In this context, two main functions of scientific journals come to the fore; the first is the dissemination of information, that is, the distribution of information, and the second is the creation of an information store for future studies, that is, archiving. In addition to publishing and archiving information, journals can also control the quality of scientific information through their respective identities and recognize the academic who owns the publication.

The first Turkish journal published during the Ottoman period was the medical journal of Vakayi-i Tıbbiye (1849-1851), published for 28 years (Yapar Gönenç, 2007, p.2). The first journal associated with the theme of Geography in Turkey started to be published by the Turkish Geographical Society shortly after the organization was established. The journal, Turkish Geographical Review, began its publication in 1943 with the aim of bringing the academic work of Turkish geographers' to both the national and international scientific community. After this journal began, the Journal of Geography from Istanbul University began publication in 1951 and the Journal of Geography Research from Ankara University began publication in 1966 (Özdemir, 2014, p. 51). Although, even until today, different geography-themed journals start their publication process, some publications have been closed. Turkish Geographical Review (1943), which started its first publication in the Republic of Turkey, continues to the present day despite occasional 
interruptions; this journal has made significant contributions to the Turkish community of Geography and international scientific communication through its continuous publication over the last 28 years.

At regular intervals during the year, journals that conduct a peer-review process of candidate publication and intend to disseminate an original study or current development of a scientific field are called academic journals (Reitz, 2014). Examining and presenting methods to reveal the structure of scientific communication generated by knowledge-sharing is defined as bibliometrics (Borgman \& Furner, 2002). The statistical analysis of different information from books, articles and other publications constitutes the essence of bibliometrics (Diodato \& Smith, 1993). Tonta and Al (2007) find that the periodical journals were grouped under three categories in their studies about Turkey's scientific publication map. The first category includes the publications that are named reference books and contain general information and outline necessary information about periodicals on specific topics. Secondly, there are monograph studies, doctoral theses, congress books, and journal special issues related to periodicals and the last group include studies on a journal published in Turkey specifically.

Between 1998 and 2002, a study about the five-year changes of journals in the fields of health, social, and technical sciences in Turkey found that journals were developed in parallel with the criteria for academic promotion and this increased the number of scientific articles published in Turkey (Kozak, 2003). A study which analyses 188 articles published in Harita Dergisi between 2000-2017 was based on articles, authors, institutions, subjects, citations, social networks, and bibliometrics laws (Polat, Saraçoğlu \& Duman, 2019).

As a result of bibliometric analysis on the journal of bilig regarding its authors' affiliations, the number of authors, the most frequently cited source type, and the journals and bibliographies, it was revealed that the majority of publications were published in Turkish and the most publication contribution was made by researchers at Gazi, Hacettepe, and Başkent Universities (Al, Soydan \& Yalçın, 2010). In their study about Turkey's policy on scientific publication, Al (2008) states that the productivity of publication in the country is focused on quantity rather than quality.

A bibliometric analysis occurs to recognize, evaluate, and monitor the articles by following an objective and transparent process which contributes to increasing the articles' quality (Borgman \& Furner, 2002; Nerur, Rasheed \& Natarajan 2008). The study of published scientific studies in terms of different variables for specific periods of time is significant in revealing the development of the relevant discipline and observing the yearly trends (Kozak, 2000). This study aims to identify the publication policies of seven Geography focused journals published in Turkey.

\section{Research Question and Sub-Questions}

In this study, the research question is, "What is publication tendency of Turkish Geography journals?" within the scope of the study, the answers to the following questions about the journals were examined: 
1. What is the historical development and publication processes for each journal?

2. What is the frequency of publication for each journal?

3. How is the editorial board structured for each journal?

4. What are the processes for publication and transparency of an article in each journal?

5. What is the objective and scope of each journal?

6. What are the index scans for each journal?

7. What is the bibliometric status of publications from Geography education academics in each journal?

The studies focus on specific Turkish journals of Geography and their publishing data within a specific time (Özdemir, 2014; Ünlü, 2020). Geography journals published in the Republic period (Sahin, 2020) were found as a result of the literature review and also included in the study. The current study differs from others because it compares the Geography journals today based on certain variables and focuses on the bibliometric analysis of academics' publications registered to YÖK Academy using geography education as a keyword. Thus, it is essential to understand the journals' historical background and current status in Geography by comparing the selected journals in terms of time, purpose, topic, and index.

\section{Methodology}

\section{Research Design}

The study was designed on a qualitative research paradigm using a dual structure. In the first section of the research, Geography-themed journals published in Turkey have been determined as the research sample, and these journals were subjected to a content analysis process.

Content analysis is a systematic process of drawing impartial conclusions from the sampled document's information (Stone, Dunphy, Marshall \& Ogilvie 1966, p. 213). Content analysis, is the process of revealing the existence of specific criteria through scanning documents such as records, books, documents (Karasar, 1995, p. 184) with the aim of revealing a neutral determination about an opinion, fact, or situation in the document (Tavşancıl \& Aslan, 2001, p. 21).

In the second section, the keyword geography education, and a bibliometric analysis process was used against the articles published by academics who were enrolled in YÖK Academy (2020). The bibliometric analysis examines and analyzes research documents or publications within the specified criteria and makes inferences for scientific communication (Ulu \& Akdağ, 2015). The bibliometrics concept, first used by Pritchard in 1969, was expressed as one that looks through a mathematical and statistical window to address the biographies of written communication tools such as books, journals, and papers (Lawani, 1981). Studies on bibliometric analyses are gathered in four different groups: citation analysis, joint citation analysis, analyses aimed at revealing individual-institution-country 
productivity, and studies focused on documents such as book-journal-article (Koehler, 2001). Through bibliometric analysis, disciplines can be discussed in terms of their differences, and journals are examined under such lens which then creates an opportunity for closer recognition of their purpose (Yalçın, 2010). In this context, Geography-themed journals published in Turkey are examined in this study.

\section{Determination of Journals}

Nine journals that publish in Turkey and use the keyword of geography education were accessed. However, two following journals were removed from the scope of the research because although Cihannuma: Journal of History and Geography Studies publishes studies about Geography within the scope of its objectives, it only publishes two human geographies publications in its first issue, and all other publications are within the scope of history discipline. Also, The Journal of the Faculty of Languages and History-Geography has a policy of publishing all Social Sciences focused articles and this means that Geography cannot be observed thematically in its publications.

In the study, seven journals are involved in the scope of the research:

J1 Turkish Journal of Geographical Sciences

J2 Eastern Geography Review

J3 Aegean Geographical Journal

J4 Istanbul University Journal of Geography

J5 International Journal of Geography and Geography Education

J6 Review of International Geographical Education (RIGE0)

J7 Turkish Geographical Review

In the current study, journals are numbered in alphabetical order, and access addresses are given in addition to the bibliography.

\section{Data Analysis}

In the data analysis, the Journal Review Form created by the researcher and the Publication Control Chart was used. In the form, there are sections such as the purpose, scope, index, publication frequency, publication type, and temporal change of the journals to determine the imprint about the journals and its general trends. In the chart, there are also sections such as the number of publications, the same number of publications, and articles with co-authors.

\section{Findings}

\section{Historical Development and Publication Process of Each Journal}

When Table 1 is analyzed, the journal that is the oldest and still in the publication is the Turkish Geographical Review. This journal still constitutes the basic structure of scholarly communication in Geography's Turkish academy. 
Table 1

Historical Developments of Turkish Geography Journals

\begin{tabular}{lllllll}
\hline & \multicolumn{1}{c}{ Journals } & $\begin{array}{l}\text { First } \\
\text { İssue }\end{array}$ & Age & $\begin{array}{l}\text { Volume } \\
\text { Issue }\end{array}$ & \multicolumn{2}{l}{$\begin{array}{l}\text { Continuous } \\
\text { Release }\end{array}$} \\
\hline J1 & Turkish Journal of Geographical Sciences & 1992 & 28 & $16 / 32^{*}$ & 2003 & 17 \\
J2 & Eastern Geographical Review & 1995 & 25 & $24 / 41^{* *}$ & 2000 & 20 \\
J3 & Aegean Geographical Journal & 1983 & 37 & $28 / 37$ & 2003 & 17 \\
J4 & Istanbul University Journal of Geography & 1985 & 35 & $-/ 38^{* * *}$ & 1996 & 24 \\
J5 & International Journal of Geography and & 1996 & 24 & $-/ 40^{* * *}$ & 2001 & 19 \\
& Geography Education (IGGE) & & & & & \\
J6 & Review of International Geographical & 2011 & 9 & $9 / 25$ & 2011 & 9 \\
J7 & Education & 1943 & 77 & $-/ 72^{* * *}$ & 1992 & 28 \\
\hline
\end{tabular}

*Refereed journal since 2003

**The 7th volume was printed two years in a row, but the numbers are given consecutively.

***No volume numbering.

Since the first issues of the journals, the ranking of them by foundation year occurs as Turkish Geographical Review, Aegean Geographical Journal, Istanbul University Journal of Geography, Turkish Journal of Geographical Sciences, Eastern Geography Review, International Journal of Geography and Geography Education, and Review of International Geographical Education (RIGEO) ${ }^{2}$.

Erinç (1973) described the four stages of geography education in Turkey: Turkey: Before the modern geography (pre-1915), the modern geography pioneers and first steps (1915-1933), the establishment and organization of the Turkish geography (1933-1941) and the rise of the Turkish geography (1942-1973) ${ }^{3}$. The Turkish Geography Congress held in 1941 in Turkey was an important event for the foundation and organization of Geography. Decisions at the congress involved the establishment of a journal for publishing scientific studies in Geography. In 1942, the Turkish Geographical Society was realized, and the Turkish Geography Institution was founded. In the following year, the Turkish Geographical Review journal began its publication life as the media tool of the institution. In this sense, it was Turkey's first scientific Geography journal.

The second oldest scientific geography journal is the Aegean Geography Journal. It is published within the Geography Department of the Faculty of Literature, Ege University, and is one of the oldest journals still published today since 2003, except

${ }^{2}$ Since the study focuses on current geography journals and ongoing publications in these journals, Turkey's journals were excluded. The historical background of Turkey geography magazines can be examined in the Academic Journal of Geography in Turkey by C. Sahin (Sahin, 2020).

${ }^{3}$ By reclassifications of the phases in geography education in 1997, Sırrı Erinç described five stages that involve turning to contemporary geography (1915-1933), the foundation and rise of Turkish scientific geography (19331982) and the last phase (after 1982) starting with YÖK (Erinç, 1997). Koçman (1999) divides those stages into five considering Erinç's first and last classification but mostly depends on the details in the first classification, which is considered the establishment and organization of Turkish geography 1933-1941. 
for certain interruptions in the past. It has been published in print until 2020, but the university committee decided to publish it electronically from hereon ${ }^{4}$.

Istanbul University Geography Journal, which started its publishing life in 1985, was published at irregular intervals till 1996 and has been published regularly for 24 years. Geography Journal is an extension of the Istanbul University Journal of Geography, published between 1951-1980 (Sahin, 2020).

The Journal of Geographical Sciences was initially called the Journal of Turkish Geography Research and Application Center in 1992 and took this name in 2001. Although it has been changed and interrupted several times, the 28-year-old journal has been publishing uninterruptedly for seventeen years since 2003 within the scope of the research center's work.

Two journals were published in 1995 and 1996 in the Faculty of Education. The first one was The Eastern Geography Journal of Atatürk University Kazım Karabekir Education Faculty, Department of Geography Education. One year later, Marmara Geography Journal started publishing under the Department of Geography Education, Faculty of Education, Marmara University. After July 2018, it changed its name to the International Journal of Geography and Geography Education (IGGE). The youngest magazine is RIGEO, which started its publishing life in 2011. It has been publishing for nine years without interruption.

Table 2

Number of Articles of Turkish Geography Journals

\begin{tabular}{|c|c|c|c|c|c|c|c|c|c|c|}
\hline \multicolumn{2}{|c|}{$\begin{array}{l}\text { Number of } \\
\text { Publications }\end{array}$} & \multirow{2}{*}{$\begin{array}{l}9 \\
\text { Years } \\
90\end{array}$} & \multirow{2}{*}{$\begin{array}{l}\mathrm{BR} \\
1\end{array}$} & \multicolumn{2}{|c|}{ Min $P$} & \multicolumn{2}{|c|}{ Max P } & \multirow{2}{*}{$\begin{array}{l}\text { IP } \\
- \\
\end{array}$} & \multirow{2}{*}{$\begin{array}{l}\text { APPI } \\
6\end{array}$} & \multirow{2}{*}{$\begin{array}{l}\text { Explanation } \\
- \\
\end{array}$} \\
\hline $\mathrm{J} 1$ & 185 & & & 8 & 2016 & 15 & $\begin{array}{l}2003 / \\
2018\end{array}$ & & & \\
\hline $\mathrm{J} 2 *$ & 527 & 200 & - & 16 & 2003 & 38 & 2008 & - & 13 & - \\
\hline $\mathrm{J} 3^{*}$ & 221 & 48 & - & 1 & 2000 & 11 & $\begin{array}{l}1984 / \\
1996 \\
\end{array}$ & 9 & 6 & - \\
\hline $\mathrm{J} 4^{*}$ & 247 & 77 & - & 4 & 2007 & 16 & 1996 & 2 & 7 & - \\
\hline J5 & 612 & 386 & - & 12 & 2004 & 54 & 2013 & 2 & 15 & - \\
\hline J6* & 149 & 149 & 18 & 10 & 2011 & 30 & 2018 & 105 & 6 & $\begin{array}{l}\text { Turkish authors for } \\
\text { the past three years }\end{array}$ \\
\hline $\mathrm{J} 7^{*}$ & 629 & 117 & 1 & 5 & 1947 & 36 & 1999 & - & 9 & $\begin{array}{l}15 \text { Notes, } \\
15 \text { Annual Reports, } \\
2 \text { Biographies }\end{array}$ \\
\hline
\end{tabular}

* There is another issue this year (2019). $\quad$ APPI: Average publication per issue.

BR: Book review MinP: Minimum publication MaxP: Maximum publication IP: International publication

Turkish Geographical Review published its first issue in 1943, and it is also the first in the theme of continuous publication with 28 years of continuous publication from 1992 to the present. Respectively, the Istanbul University Journal of Geography, Eastern Geography Review, and International Journal of Geography and

${ }^{4}$ However, a university's first geography journal was the Journal of Istanbul University Geography Institute, which published 23 issues between 1951-1980. Following the institute's closure in 1982, it ended publications (Sahin, 2020, p: 186-187). 
Geography Education has 24, 20, and 19 years of publication. Four of the seven journals are published using volume and issue while three do not use volume numbers. Three of the journals originated in Istanbul, while others in Ankara, Izmir, Erzurum, and Eskisehir. This case can be interpreted as the fact that rooted faculties gave birth to rooted journals.

When Table 2 is examined, it is seen that most articles have been published in the oldest journal, Turkish Geographical Review (f:629). This is followed by the International Journal of Geography and Geography Education (f:612) and Eastern Geography Review (f:527). Although the Istanbul University Journal of Geography is the second oldest journal, it is ranked 4thin the publication rankings. This ranking may be misleading, given that the period of publication of the journals is interrupted and their lifetimes are not equal, and the number of publications for the last nine years has been checked over the journals' age with the shortest life span. In the last nine years, the distribution was between 386 and 48 publications, and the most publications were published in International Journal of Geography and Geography Education (f:386), followed by Eastern Geography Review (f:200). In third place is Review of International Geographical Education (RIGE0), which was the newest among all. The least publications occur in Aegean Geographical Journal with 43 articles. Although RIGEO is the newest journal, it has taken its place among other journals in the last nine years. To observe the quantitative comparison more clearly, unlike the total number of journals' publications, the publication per issue (volume/issue) of the journals was checked and is given in Chart 1. When Chart 1is examined, it is determined that most publications per issue in Turkish Geography journals were in the International Journal of Geography and Geography Education (f: 15) and Eastern Geography Review (f: 13).

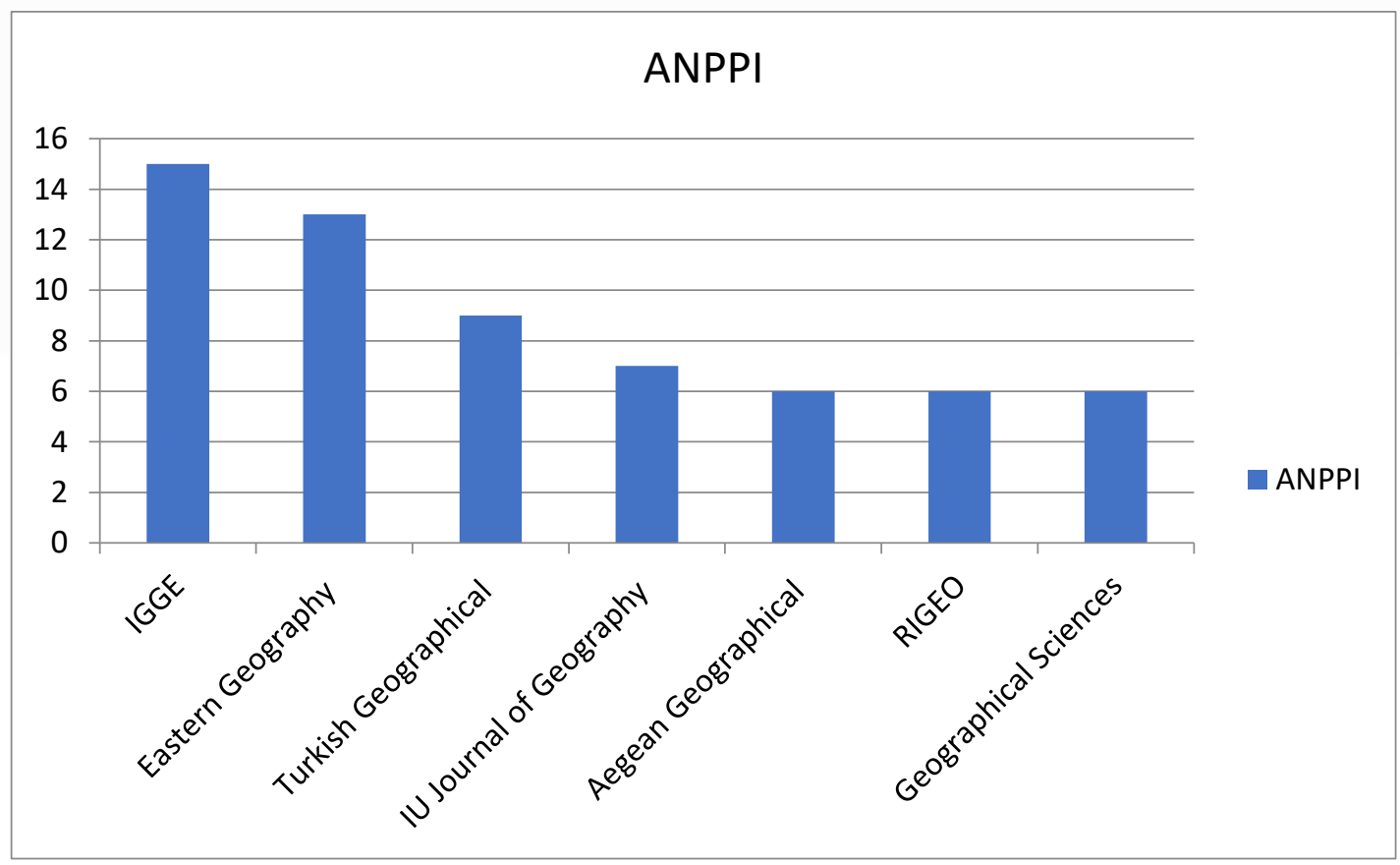

Figure1. Average Number of Publications Published per Issue in Turkish Geography Journals 
The journals with the years of least publication are the Aegean Geographical Journal (2000) with one publication, and the Istanbul University Journal of Geography (2007) with four publications. The journals with the year of most publication was the International Journal of Geography and Geography Education (2013) with 54 publications, followed by Eastern Geography Review (2008) with 38 publications, and the Turkish Geographical Review (1999) with 36 publications, respectively. While no international publications were published in four journals (Turkish Journal of Geographical Sciences, Eastern Geography Review, International Journal of Geography and Geography Education, and Turkish Geographical Review), there are international publications in three journals (Aegean Geographical Journal, Istanbul University Journal of Geography, and RIGE0). 115 of 149 publications in RIGEO were written by international authors and 34 by Turkish authors. Only the last three issues of this journal featured Turkish authors from Turkey. Within the journals' publication policies, three journals contribute to the field through a book review, apart from publishing articles. With nine book reviews, RIGEO ranks first in this category. All of the reviewed books are international publications. The Turkish Journal of Geographical Sciences and Turkish Geographical Review has also published a book review article. The Turkish Geographical Review, which is the Turkish Geographical Society's publishing body, is leading the way in contributing to different aspects of the field with 15 notes, 14 annual reports, and two biographies.

\section{Frequency of Publication of Each Journal}

While six of the journals are published bi-annually, only RIGEO is published tri-annually. Readers of all the journals encounter 15 issues during the year. Five of these issues meet their readers in December and four in June.

Table 3

Publication Frequency of Turkish Geography Journals during the Year

\begin{tabular}{lllllllll}
\hline Journals & January & April & June & July & August & October & December & Total \\
\hline J1 & & X & & & & X & & 2 \\
J2 & & & X & & & & X & 2 \\
J3 & & & X & & & & X & 2 \\
J4 & & & X & & & & X & 2 \\
J5 & X & & & X & & & & 2 \\
J6 & & X & & & X & & X & 3 \\
J7 & & & X & & & & X & 2 \\
\hline Total & 1 & 2 & 4 & 1 & 1 & 1 & 5 & 15 \\
\hline
\end{tabular}

In seven different months, journals publish at least one issue. No Geography journal is published for five months, including February, March, May, September, and November.

\section{Editorial Board Structure of Each Journal}

Table 4 shows a structure in the journals' top organizational structure, including the editor-in-chief, the editors, and the editorial board. While there are editors-inchief in four journals, including the Turkish Journal of Geographical Sciences, Istanbul University Journal of Geography, RIGEO, and Turkish Geographical Review; 
there are managers for Eastern Geography Review and Aegean Geographical Journal. However, this editorial board is not available in the International Journal of Geography and Geography Education.

Table 4

Editorial and Publishing Board of Turkish Geography Journals

\begin{tabular}{lllllllll}
\hline & $\mathrm{J} 1$ & $\mathrm{~J} 2$ & $\mathrm{~J} 3$ & $\mathrm{~J} 4$ & $\mathrm{~J}$ & & $\mathrm{~J} 6$ & $\mathrm{J7}$ \\
\hline Editor-in-Chief / Manager & $\mathrm{EC}$ & $\mathrm{M}$ & $\mathrm{M}$ & $\mathrm{EC}$ & - & $\mathrm{EC}$ & $\mathrm{EC}$ \\
$\begin{array}{l}\text { Editor/Administrative Editor / } \\
\text { International Editor }\end{array}$ & $4 \mathrm{E}+1 \mathrm{AE}$ & $2 \mathrm{E}$ & $3 \mathrm{E}$ & - & $2 \mathrm{E}$ & $6 \mathrm{IE}$ & - \\
\hline Publication / Editor / Advisory Board & $\mathrm{AB}$ & $\mathrm{PB}$ & $\mathrm{PB}$ & $\mathrm{PB}$ & $\mathrm{PB}$ & $\mathrm{EB}$ & $\mathrm{PB}$ \\
Person & 31 & 11 & 40 & 15 & 18 & 41 & 7 \\
Domestic Insider & 6 & 6 & 15 & 5 & 5 & 7 & 5 \\
Native Outside & 19 & 5 & 18 & 3 & 10 & & - \\
Foreign & 6 & - & 7 & 7 & 3 & 34 & 2 \\
\hline How many different universities* & 16 & 5 & 16 & 10 & 13 & 39 & 5 \\
Domestic & 10 & 5 & 9 & 3 & 10 & 7 & 3 \\
Foreign & 6 & - & 7 & 7 & 3 & 32 & 2 \\
\hline Strictly Closed Inside & & & & & & & \\
Strictly Closed Outside & & & & & & & \\
\hline
\end{tabular}

*The publishing university not included in the figures.

Although the editor-in-chief expression is used in the Istanbul University Journal of Geography and Turkish Geographical Review, there is no editorship. Unlike other journals, one administrative editor was added to four editors under one editor-inchief in the Turkish Journal of Geographical Sciences. With $77 \%$ of its publications being made up of international publications, RIGEO has an additional six international editors on its editorial board.

When the editorial board for the upper editorial structure is examined, there are five journals which use the term Publication Board, however, the Turkish Journal of Geographical Sciences preferred to use the expression of Advisory Board and RIGEO uses Editorial Board. The editorial boards of the journals range from 41 to seven academics. The journals with the most academics on the editorial board are RIGEO (f:41) and Aegean Geographical Journal (f:40), while the journal with the least academics is the Turkish Geographical Review (f:7). While there are no international editorial board members only in Eastern Geography Review, there are international board members in RIGEO (f:34), Aegean Geographical Journal (f:7), Istanbul University Journal of Geography (f:7),Turkish Journal of Geographical Sciences (f:6), International Journal of Geography and Geography Education (f:3) and Turkish Geographical Review (f:2). When examining how many faculty members from different universities are included in the journals' editorial boards, it is determined that a maximum of 39 faculty members from at least five different universities are included in the editorial boards of the journals. RIGEO (f:39) hosts the most editorial board members from different universities, while the Turkish Journal of Geographical Sciences and Aegean Geographical Journal have board members from sixteen different universities. Considering the board members' formation from different universities, the most closed journal to its university, both national and 
international, is Eastern Geography Review. Although there are no international members in its editorial board, all of its members are from different universities and are either graduate or doctorate graduates of the university where the journal is affiliated. There are editorial board members from 3 different universities for the Istanbul University Journal of Geography, two of which have been students of the university in the past. Although it is not strictly closed inside, compared to the other five journals it can be said that it is partially closed on a national basis regarding the composition of the editorial board.

\section{Publication Processes and Transparency of an Article in Each Journal}

When the publication processes and transparency of the journals are checked, it can be said that qualitatively, they are good in terms of the arrival date, acceptance date, revision date, referee, and first author information.

Table 5

Publication Process of Turkish Geography Journals

\begin{tabular}{|c|c|c|c|c|c|c|}
\hline Journals & Received & Accepted & Revised & $\begin{array}{l}\text { Referee } \\
\text { Information }\end{array}$ & $\begin{array}{l}\text { Responsible } \\
\text { Author }\end{array}$ & $\begin{array}{l}\text { Total } \\
\text { Criteria }\end{array}$ \\
\hline $\mathrm{J} 1$ & $*$ & $*$ & - & $*$ & * & 4 \\
\hline $\mathrm{J} 2$ & $*$ & $*$ & - & $*$ & * & 4 \\
\hline $\mathrm{J} 3$ & $*$ & $*$ & $*$ & $*$ & $*$ & 5 \\
\hline J4 & $*$ & $*$ & $*$ & $*$ & $*$ & 5 \\
\hline J5 & $*$ & $*$ & $*$ & $*$ & * & 5 \\
\hline J6 & $*$ & $*$ & $*$ & $*^{a}$ & * & 5 \\
\hline J7 & $*$ & $*$ & - & $* \mathrm{~b}$ & $*$ & 4 \\
\hline
\end{tabular}

When the most recent one-year process for publication was analyzed, three journals, RIGEP, the Aegean Geographical Journal and International Journal of Geography and Geography Education carried all five criteria; also, the Istanbul University Journal of Geography moved up to this level. Other journals have a total of four criteria. Eastern Geography Review, which had only two criteria a year ago, has reached four criteria today.

\section{Objective and Scope of Each Journal}

The objective and scope of the journals are addressed in this section. Mainly, the statements stated in the two titles were subject to a single analysis because the journals used their objective statements in their scope statements. It is noted that when the objectives and scopes of the journals are checked, there are general expressions that are inclusive, and they do not contain details. Objective and scope are covered in 5 different categories: field of study, education, research methods, focus problem, and specific objective.

Each journal related to the field of study has a specific objective. While four journals emphasize the dual structure of Geography, four journals emphasize all of the geographical sciences. The most specific field of study belongs to Eastern Geography Review with its reference to the eastern Geography and the CaucasusCentral Asia Turkish Geography. The Turkish Journal of Geographical Sciences only 
uses the prioritization of Turkish Geography. RIGEO emphasizes globally focused work due to its preference for international publication and geographical education.

Only four of the journals announce that they could publish education within the scope of their publication policy. Eastern Geography Review, Aegean Geographical Journal, International Journal of Geography and Geography Education, and RIGEO have accepted studies in geographical education. In contrast, only Eastern Geography Review and RIGEO have opened their pages to educational publications within the scope of Social Sciences scope as well as with Geography.

Table 6

The Objective and Scope of Turkish Geography Journals

\begin{tabular}{|c|c|c|c|c|c|c|c|c|c|}
\hline \multicolumn{2}{|r|}{ Objective } & \multirow{2}{*}{$\mathbf{J 1}$} & \multirow{2}{*}{$\mathbf{J} 2$} & \multirow{2}{*}{$\mathbf{J 3}$} & \multirow{2}{*}{4} & \multirow{2}{*}{$\mathbf{J 5}$} & \multirow{2}{*}{ J6 } & \multirow{2}{*}{ J7 } & \multirow{2}{*}{ Total } \\
\hline Category & Expression & & & & & & & & \\
\hline \multirow{6}{*}{$\begin{array}{l}\text { Field of } \\
\text { Study }\end{array}$} & $\begin{array}{l}\text { Research on Physical/Human and } \\
\text { Economic Geography }\end{array}$ & & & $\mathrm{X}$ & $X$ & $\mathrm{X}$ & & $X$ & 4 \\
\hline & $\begin{array}{l}\text { Authentic study of geographical } \\
\text { sciences }\end{array}$ & $\mathrm{X}$ & $X$ & $\mathrm{X}$ & & $\mathrm{X}$ & & & 4 \\
\hline & Studies on Turkish Geography & $\mathrm{X}$ & & & & & & & 1 \\
\hline & Eastern Region studies & & $\mathrm{X}$ & & & & & & 1 \\
\hline & $\begin{array}{l}\text { Future target studies of Caucasian } \\
\text { and Central Asian Turkish countries }\end{array}$ & & $\mathrm{X}$ & & & & & & 1 \\
\hline & $\begin{array}{l}\text { Globally oriented work because of } \\
\text { international coverage }\end{array}$ & & & & & & $\mathrm{X}$ & & 1 \\
\hline \multirow{4}{*}{ Education } & Geography education & & $\mathrm{X}$ & $\mathrm{X}$ & & $\mathrm{X}$ & $\mathrm{X}$ & & 4 \\
\hline & Field education of Social Sciences & & $\mathrm{X}$ & & & & & & 1 \\
\hline & Social studies education & & & & & & $\mathrm{X}$ & & 1 \\
\hline & $\begin{array}{l}\text { Other educational publications in } \\
\text { contact with geography education } \\
\text { (environment, biology, geology, etc.) }\end{array}$ & & & & & & $\mathrm{X}$ & & 1 \\
\hline \multirow{3}{*}{$\begin{array}{l}\text { Research } \\
\text { Methods }\end{array}$} & $\begin{array}{l}\text { Quality publication in international } \\
\text { standards }\end{array}$ & $\mathrm{X}$ & & & & $\mathrm{X}$ & & & 2 \\
\hline & Empirical and review studies & $\mathrm{X}$ & & $\mathrm{X}$ & & & & & 2 \\
\hline & $\begin{array}{l}\text { Studies with new scientific methods } \\
\text { and techniques applied }\end{array}$ & $\mathrm{X}$ & & & & & & & 1 \\
\hline \multirow[b]{2}{*}{$\begin{array}{l}\text { Focus } \\
\text { Problem }\end{array}$} & $\begin{array}{l}\text { Understanding physical and nature- } \\
\text { human Relations and its systematics }\end{array}$ & & & & $\mathrm{X}$ & & & $X$ & 2 \\
\hline & $\begin{array}{l}\text { Closing the gap between theory and } \\
\text { practice in Geography and Social } \\
\text { Studies }\end{array}$ & & & & & & $\mathrm{X}$ & & 1 \\
\hline \multirow[t]{2}{*}{$\begin{array}{c}\text { Specific } \\
\text { Objective }\end{array}$} & $\begin{array}{l}\text { Publishing the publications of our } \\
\text { university geographers }\end{array}$ & & $\mathrm{X}$ & & & & & & 1 \\
\hline & Total & 5 & 6 & 4 & 2 & 4 & 5 & 2 & 28 \\
\hline
\end{tabular}

Only three different journals (Turkish Journal of Geographical Sciences, Aegean Geographical Journal, and International Journal of Geography and Geography Education) emphasize the nature of research methods in the submitted studies. The phrase "quality publication in international standards" is used by two journals. There are two journals (empirical and review) that report a direct preference for the study method. The emphasis on using contemporary methods and techniques is made only by the Turkish Journal of Geographical Sciences.

While the Istanbul University Journal of Geography, RIGE0, and Turkish Geographical Review form an objective by stating the journals' focus, only Eastern 
Geography Review creates a specific objective titled "the studies of our university geographers."

\section{Index Scans of Each Journal}

When the index scans of the Turkish journals for Geography are examined, it is observed that Turkish Geographical Review and RIGEO have six indices which suggests they are the most indexed journals. They are followed by the International Journal of Geography and Geography Education which has five indices.

Table7

The Index Scans of Turkish Geography Journals

\begin{tabular}{|c|c|c|c|c|c|c|c|c|}
\hline Index & $\mathrm{J} 1$ & $\mathrm{~J} 2$ & $\mathrm{~J} 3$ & $\mathrm{~J} 4$ & $\mathrm{~J} 5$ & J6 & $\mathrm{J} 7$ & Total \\
\hline ASOS INDEX & $\mathrm{X}$ & & & & & & $\mathrm{X}$ & 2 \\
\hline DOAJ & & & & & $\mathrm{X}$ & & & 1 \\
\hline EBSCO Education Source & & & & & & $\mathrm{X}$ & & 1 \\
\hline EBSCOhost & & $\mathrm{X}$ & & & $\mathrm{X}$ & & & 2 \\
\hline Elsevier-Scopus & & & & & & $\mathrm{X}$ & & 1 \\
\hline Emerging Sources Citation Index (ESCI) & & & & $\mathrm{X}$ & $\mathrm{X}$ & & & 2 \\
\hline ERIC & & & & & & $\mathrm{X}$ & & 1 \\
\hline Google Scholar & & $\mathrm{X}$ & & & & & $\mathrm{X}$ & 2 \\
\hline Index Copernicus & & & & & & $\mathrm{X}$ & $\mathrm{X}$ & 2 \\
\hline INFORMIT Indexes & & & & & & $\mathrm{X}$ & & 1 \\
\hline Journal Seek & & & & & & & $\mathrm{X}$ & 1 \\
\hline Sobiad & $\mathrm{X}$ & $\mathrm{X}$ & & & & & $\mathrm{X}$ & 3 \\
\hline TR Dizin (ULAKBİM) & $\mathrm{X}$ & & $\mathrm{X}$ & & $\mathrm{X}$ & $\mathrm{X}$ & $\mathrm{X}$ & 5 \\
\hline Ulrich's Periodicals Directory & & & & & $\mathrm{X}$ & & & 1 \\
\hline Total Different Index & 3 & 3 & 1 & 1 & 5 & 6 & 6 & 25 \\
\hline Quality Level* & & & & & & & & \\
\hline
\end{tabular}

*The color scale from light gray to dark black was used to interpret the index quality level.

Although this is the case in quantitative terms, when an evaluation is made in terms of the quality of indices' quality, the most qualified journal is RIGEO, which is scanned in the international area index (ERIC) and based on the criteria of the Associate Professorship in Turkey. It is followed by the International Journal of Geography and Geography Education and Istanbul University Journal of Geography, respectively, which are scanned in the ESCI index. Considering that there must at least two ULAKBIM indexed publication requirements in Turkey's Associate Professorship criteria, five of the seven Geography journals bear this requirement. However, Eastern Geography Review is scanned in three different indices but does not meet the current requirements based on Turkey's Associate Professorship criteria and scoring system.

\section{Bibliometric Status of Publication from Geography Education Academics in Each Journal}

"YÖK Academic" has been used as a data source to identify academics working in Geography education. Seventy-four academics use the keyword geography education in YÖK Academic. Eighteen of these academics were excluded from the study because they were academics who were in retirement or from other major disciplines, or who were only co-publishing in Geography as part of their work in 
interdisciplinary studies. Of the 56 academics included in the study, 15 were Professors, 15 were Associate Professors, 20 were Assistant Professors, and 6 were research assistants. The bibliometric status of academics in Geography education who publish in Turkish journals of Geography journals is shown below in Table 8.

Table 8

Bibliometric Status of Geography Education Academicians in Turkish Geography Journals

\begin{tabular}{|c|c|c|c|c|c|c|c|c|c|c|c|c|c|}
\hline \multicolumn{2}{|c|}{ Journals } & \multicolumn{2}{|c|}{$\begin{array}{l}\text { Eastern } \\
\text { Geograph } \\
\text { y }\end{array}$} & \multicolumn{2}{|c|}{$\begin{array}{l}\text { IU Journal } \\
\text { of } \\
\text { Geography }\end{array}$} & \multicolumn{2}{|c|}{$\begin{array}{l}\text { Marmara } \\
\text { (IGGE) }\end{array}$} & \multicolumn{2}{|c|}{ RIGEO } & \multicolumn{2}{|c|}{$\begin{array}{l}\text { Turkish } \\
\text { Geographi } \\
\text { cal }\end{array}$} & \multicolumn{2}{|c|}{ Total } \\
\hline $\mathrm{f}$ & Titles & $\mathrm{f}$ & PPC & f & PPC & $\mathrm{f}$ & PPC & $\mathrm{f}$ & PPC & $\mathrm{f}$ & PPC & $\mathrm{f}$ & PPC \\
\hline $\begin{array}{l}1 \\
5\end{array}$ & Prof. & 38 & 2,5 & 3 & 0,2 & 65 & 4,3 & 9 & 0,6 & 7 & 0,5 & 122 & 8,1 \\
\hline $\begin{array}{l}1 \\
5\end{array}$ & $\begin{array}{l}\text { Assoc. } \\
\text { Prof. }\end{array}$ & 6 & 0,4 & - & - & 47 & 3,1 & 4 & 0,3 & 2 & 0,1 & 59 & 3,9 \\
\hline $\begin{array}{l}2 \\
0\end{array}$ & $\begin{array}{l}\text { Asst. } \\
\text { Prof. }\end{array}$ & 26 & 1,3 & - & - & 26 & 1,3 & 5 & 0,3 & 6 & 0,3 & 63 & 3,2 \\
\hline 6 & $\begin{array}{l}\text { Resear } \\
\text { ch Asst. }\end{array}$ & 2 & 0,3 & - & - & 8 & 1,3 & 3 & 0,5 & - & - & 13 & 2,2 \\
\hline $\begin{array}{l}5 \\
6\end{array}$ & Total & 72 & 1,3 & 3 & 0,1 & 146 & 2,6 & 21 & 0,4 & 15 & 0,3 & 257 & 4,6 \\
\hline
\end{tabular}

When Table 8 is examined, it is determined that the academics of Geography education published in five of the seven journals selected for the current research; and they have not published in the Turkish Journal of Geographical Sciences and Eastern Geography Review. Considering that Geographers of pure origin with the Professor's title published three publications in the Istanbul University Journal of Geography, it can be said that this journal avoided the work of Geography education academics.

When the publications in the journals are compared according to the academic title, it is determined that, as a requirement of academic development, the total publications show an increasing trend from research assistants (f:13, Avg:2,2) towards Professors (f:122, Avg:8,1). In terms of all academic titles, only three journals, namely Marmara, Eastern Geography Review, and RIGE0 publishes articles from academics with each title.

International Journal of Geography and Geography Education (f: 146, Avg: 2,6) are the most common journals in which Geography education academics publish. In this sense, it is not wrong to claim that the pulse of Turkish Geography education publications' beats in this journal. In the second place, the Eastern Geography Review (f:72, Avg:1,3) has the most widely published articles. However, given that the International Journal of Geography and Geography Education have been publishing continuously for 19 years and Eastern Geography Review for 20 years, and RIGEO has only been publishing for nine years, it can be suggested that RIGEO has acquired a special place in this field, considering the scanned indices. Given the lack of publications in the Turkish Journal of Geographical Sciences and Aegean Geographical Journal and the scarcity of publications in Istanbul University Journal of Geography and Turkish Geographical Review, it is not wrong to claim that 
academics who use the keyword of geography education have avoided pure Geography studies.

After taking a general overview of Geography education academics' publications in Turkish journals of Geography, the academic titles' and publications are detailed separately in Table 9, Table 10, Table 11, and Table 12.

Although 17 Professors used the keyword of geography education at YÖK Academy, 15 Professors, two of whom were excluded from the study because they are not in the field, have been examined. There are 575 publications by the Professors and only 122 items are published in Turkish journals of Geography. It indicates that approximately one quarter (21\%) of the publications from the geography education academics who hold the title of Professor's, are published in Turkish journals of Geography. While there are 26 publications in the Turkish journals of Geography for academics with a Professor's title, one Professor has never published in any of these journals although four of the Professors have published in four different Turkish journals of Geography.

Table 9

Bibliometric Status of Geography Education Professors in Turkish Geography Journals

\begin{tabular}{|c|c|c|c|c|c|c|c|c|c|}
\hline \multirow[t]{2}{*}{ Professor } & \multirow{2}{*}{$\begin{array}{l}\text { Number of } \\
\text { Publications }\end{array}$} & \multicolumn{2}{|c|}{$\begin{array}{c}\text { Geography } \\
\text { Journals }\end{array}$} & \multirow[t]{2}{*}{$\mathrm{J} 2$} & \multirow[t]{2}{*}{$\mathrm{J} 4$} & \multirow[t]{2}{*}{$\mathrm{J} 5$} & \multirow[t]{2}{*}{$\mathrm{J} 6$} & \multirow[t]{2}{*}{$\mathrm{J} 7$} & \multirow[t]{2}{*}{$\mathrm{DJP}$} \\
\hline & & $\mathrm{f}$ & $\%$ & & & & & & \\
\hline 1 & 45 & 26 & 58 & 23 & & 1 & 2 & & 3 \\
\hline 2 & 42 & 17 & 41 & 4 & & 11 & & 2 & 3 \\
\hline 3 & 33 & 12 & 36 & 1 & & 6 & 2 & 3 & 4 \\
\hline 4 & 35 & 12 & 34 & 3 & & 8 & 1 & & 3 \\
\hline 5 & 37 & 8 & 22 & & & 8 & & & 1 \\
\hline 6 & 67 & 8 & 12 & 3 & & 4 & 1 & & 4 \\
\hline 7 & 35 & 8 & 23 & & & 8 & & & 2 \\
\hline 8 & 120 & 6 & 5 & 1 & 3 & 1 & & 1 & 4 \\
\hline 9 & 27 & 6 & 22 & & & 4 & 2 & & 2 \\
\hline 10 & 16 & 6 & 38 & & & 6 & & & 1 \\
\hline 11 & 22 & 5 & 23 & 1 & & 4 & & & 3 \\
\hline 12 & 18 & 5 & 28 & 2 & & 1 & 1 & 1 & 4 \\
\hline 13 & 37 & 2 & 5 & & & 2 & & & 2 \\
\hline 14 & 17 & 1 & 6 & & & 1 & & & 2 \\
\hline 15 & 24 & - & - & & & & & & \\
\hline Total & 575 & 122 & 21 & 38 & 3 & 65 & 9 & 7 & \\
\hline$\%$ & & 21 & & 29 & 2 & 53 & 7 & 6 & \\
\hline
\end{tabular}

Note: * DJP: The academician refers to how many different journal publishers.

Even though 19 Associate Professors used the keyword of geography education at YÖK Academy, 15 Associate Professors were involved in the study. Four were excluded because they were not directly involved in Geography education but were interdisciplinary academics.

Although 15 Associate Professors have 364 publications, only 59 of the publications are in Turkish journals of Geography; this shows that $16 \%$ of Geography education publications from Associate Professors' are published in Turkish journals of Geography. While there is a maximum of 30 publications among Associate Professors from Turkish journals of Geography, there are three Associate 
Professors with no publication in the Turkish journals of Geography. When examining how many different journals the Associate Professors publishing in amongst the seven chosen journals for the current study, the publications are seen in only two different journals.

Table 10

Bibliometric Status of Geography Education Associate Professors in Turkish Geography Journals

\begin{tabular}{|c|c|c|c|c|c|c|c|c|}
\hline \multirow{2}{*}{$\begin{array}{l}\text { Associate } \\
\text { Professor }\end{array}$} & \multirow{2}{*}{$\begin{array}{l}\text { Number of } \\
\text { Publications }\end{array}$} & \multicolumn{2}{|c|}{$\begin{array}{l}\text { Geography } \\
\text { Journals }\end{array}$} & \multirow[t]{2}{*}{$\mathrm{J} 2$} & \multirow[t]{2}{*}{ J5 } & \multirow[t]{2}{*}{ J6 } & \multirow[t]{2}{*}{ J7 } & \multirow[t]{2}{*}{ DJP* } \\
\hline & & $\mathrm{f}$ & $\%$ & & & & & \\
\hline 1 & 12 & & & & & & & - \\
\hline 2 & 20 & 2 & 10 & & 2 & & & 1 \\
\hline 3 & 38 & 1 & 3 & & 1 & & & 1 \\
\hline 4 & 28 & 2 & 7 & 1 & & 1 & & 2 \\
\hline 5 & 26 & 1 & 4 & & 1 & & & 1 \\
\hline 6 & 27 & 1 & 4 & & & 1 & & 1 \\
\hline 7 & 29 & 9 & 31 & & 9 & & & 1 \\
\hline 8 & 42 & 30 & 7 & & 29 & & 1 & 2 \\
\hline 9 & 31 & 1 & 3 & & & 1 & & 1 \\
\hline 10 & 12 & & & & & & & - \\
\hline 11 & 13 & & & & & & & - \\
\hline 12 & 20 & 1 & 5 & & 1 & & & 1 \\
\hline 13 & 14 & 1 & 7 & 1 & & & & 1 \\
\hline 14 & 24 & 5 & 21 & 4 & & 1 & & 2 \\
\hline 15 & 28 & 5 & 18 & & 4 & & 1 & 2 \\
\hline Total & 364 & 59 & 16 & 6 & 47 & 4 & 2 & \\
\hline$\%$ & & 16 & & 1,5 & 13 & 1 & 0,5 & \\
\hline
\end{tabular}

Twenty-six Assistant Professors at YÖK Academy used the keywords of geography education, but because five were not directly involved in Geography education and were interdisciplinary academics and one Assistant Professor was on leave, they were excluded from the study. As a result, a total of 20 Assistant Professors were included in the study.

Twenty academics with the title of Assistant Professor have 275 publications, but only 60 of these publications are published in Turkish journals of Geography. It shows that 22\% of the Assistant Professor academic publications are published in Turkish journals of Geography. While Assistant Professor Doctors have a maximum of 22 publications in Turkish journals of Geography, six Assistant Professors have never published in any of these journals. When examining how many different journals Assistant Professors publish in out of the seven selected journals it is only seen that publication occurs only in two different journals. 
Table 11

Bibliometric Status of Geography Education Assistant Professors in Turkish Geography Journals

\begin{tabular}{|c|c|c|c|c|c|c|c|c|}
\hline \multirow{2}{*}{$\begin{array}{l}\text { Assistant } \\
\text { Professors }\end{array}$} & \multirow{2}{*}{$\begin{array}{l}\text { Number of } \\
\text { Publications }\end{array}$} & \multicolumn{2}{|c|}{$\begin{array}{l}\text { Geography } \\
\text { Journals }\end{array}$} & \multirow[t]{2}{*}{$\mathrm{J} 2$} & \multirow[t]{2}{*}{ J5 } & \multirow[t]{2}{*}{ J6 } & \multirow[t]{2}{*}{ J7 } & \multirow[t]{2}{*}{ DJP* } \\
\hline & & $\mathrm{f}$ & $\%$ & & & & & \\
\hline 1 & 3 & - & - & & & & & - \\
\hline 2 & 16 & 5 & 31 & & 4 & 1 & & 2 \\
\hline 3 & 14 & 3 & 21 & & 1 & & 2 & 2 \\
\hline 4 & 4 & 1 & 25 & 1 & & & & 1 \\
\hline 5 & 17 & 3 & 18 & & 1 & 2 & & 2 \\
\hline 6 & 15 & 4 & 27 & & 2 & 2 & & 2 \\
\hline 7 & 12 & 2 & 17 & & 1 & & 1 & 2 \\
\hline 8 & 20 & 1 & 5 & & & 1 & & 1 \\
\hline 9 & 7 & 3 & 43 & 2 & & & 1 & 2 \\
\hline 10 & 17 & 2 & 12 & & 2 & & & 1 \\
\hline 11 & 11 & - & - & & & 1 & & - \\
\hline 12 & 7 & - & - & & & & & - \\
\hline 13 & 12 & - & - & & 5 & & & 1 \\
\hline 14 & 30 & 22 & 73 & 21 & - & & 1 & 2 \\
\hline 15 & 48 & 5 & 10 & & 4 & & 1 & 2 \\
\hline 16 & 13 & 2 & 15 & 1 & 1 & & & 2 \\
\hline 17 & 3 & - & - & & & & & - \\
\hline 18 & 21 & 6 & 29 & 1 & 5 & & & 2 \\
\hline 19 & 4 & 1 & 25 & & 1 & & & 1 \\
\hline 20 & 1 & - & - & & & & & - \\
\hline Total & 275 & 60 & 22 & 26 & 27 & 7 & 6 & \\
\hline$\%$ & & 22 & & 43 & 45 & 12 & 10 & \\
\hline
\end{tabular}

Note: * DJP: The academician refers to how many different journal publishers.

Although nine research assistants at YÖK Academy used the keyword of geography education, only six research assistants were excluded from the study because three of them were not directly involved in Geography education but were interdisciplinary academics.

Table 12

Bibliometric Status of Geography Education Research Assistants in Turkish Geography Journals

\begin{tabular}{|c|c|c|c|c|c|c|c|}
\hline \multirow{2}{*}{$\begin{array}{l}\text { Research } \\
\text { Assistants }\end{array}$} & \multirow{2}{*}{$\begin{array}{l}\text { Number of } \\
\text { Publications }\end{array}$} & \multicolumn{2}{|c|}{ Geography Journals } & \multirow{2}{*}{$\mathrm{J} 2$} & \multirow{2}{*}{$\mathrm{J} 5$} & \multirow{2}{*}{$\mathrm{J} 6$} & \multirow{2}{*}{ DJP } \\
\hline & & $\mathrm{f}$ & $\%$ & & & & \\
\hline 1 & 3 & - & - & & & & - \\
\hline 2 & - & - & - & & & & - \\
\hline 3 & 21 & 7 & 33 & 1 & 5 & 1 & 3 \\
\hline 4 & 3 & 2 & 67 & & 2 & & 1 \\
\hline 5 & 5 & 2 & 40 & & & 2 & 1 \\
\hline 6 & 4 & 2 & 50 & 1 & 1 & & 2 \\
\hline Total & 36 & 13 & 36 & 2 & 8 & 3 & \\
\hline$\%$ & & 36 & & 6 & 22 & 8 & \\
\hline
\end{tabular}

Note: ${ }^{*}$ DJP: The academic refers to how many different journal publishers. 
When the publications are examined of research assistants (who are at the beginning of their academic career) in Turkish journals of Geography, it can be seen that 13 out of 36 publications were published in three journals. These journals, from the most published to the least, are the International Journal of Geography and Geography Education ( $n=8)$, RIGEO ( $n=3)$, and Eastern Geography Review ( $n=2)$.

\section{Conclusion and Suggestions}

Scientific journals are one of the communication bodies of the academic world. Research on journals provide clues about the period of development for that journal. In this study, which aims to reveal the publication tendency of Geography journals being published in Turkey, there were seven journals of Geography examined in the context of publication periods and historical development processes, publication frequency, editorial and board structures, article publication process and scanned indices. The oldest geography-themed journal in the Turkish Geography academy is the Turkish Geographical Review, which began publication in 1943. The journal has been published continuously for 28 years and is the longest-running journal among the seven journals analyzed. It is followed by the Istanbul University Journal of Geography with 24 years of continuous publication, Eastern Geography Review with 20 years of continuous publication, and International Journal of Geography and Geography Education with 19 years of continuous publication. The newest journal is RIGEO, which has been publishing for nine years now. Three journals are based in Istanbul, while the others are based in Ankara, Izmir, Erzurum, and Eskisehir. This case can be interpreted as the fact that rooted faculties gave birth to rooted journals.

It has been determined that most articles have been published in Turkish Geographical Review, followed by the International Journal of Geography and Geography Education and Eastern Geography Review. Although the Istanbul University Journal of Geography is the second oldest journal of Geography, it is ranked fourth in publication rankings using quantitative terms. When the publication periods of the journal are considered not to be equal, it was observed, based on the analysis in terms of the newest journal, that most publications occurred in the International Journal of Geography and Geography Education, followed by Eastern Geography Review and RIGEO, which is the newest one. Although RIGEO is the newest journal, it has secured its place among other journals on a quantitative basis. The number of publications per issue were analyzed, and it was found that most publications per issue were published in the International Journal of Geography and Geography Education and Eastern Geography Review.

While six journals are published bi-annually, only RIGEO is published triannually. Readers of all the journals will encounter 15 issues in seven different months during the year. When assessing a scientific journal, six criteria can be used: visibility (recognition), quality, respectability, communication, ethical and legal dimension, and period of publication. The publication period is addressed under two titles: regular and periodical publication (Gökce Kutsal, 2019, p. 241). Turkish journals for Geography have been published for many years and can be interpreted as providing regular issues in a publication period.

There was a structure in the upper organizational system of journals, including the editor-in-chief, editors, and editorial board. The editorial boards of journals 
ranged between 41 and seven academics. The most populous editorial boards occur in the journals of RIGEO and the Aegean Geographical Journal, while the journal with the least number of academics on the editorial board is the Turkish Geographical Review. No more than 39 names of at least five different universities were found on the editorial boards. RIGEO has the most significant number of editorial board members from different universities. In this context, it can be claimed that the Istanbul University Journal of Geography is partially self-enclosed while Eastern Geography Review is the most enclosed journal within a university, both at the national and international levels. Editors have responsibilities about the control of publication process, journal's policy, preservation of objective and scope, and regularity of publication and the readers' accuracy, the scientific value of the published work, and subject to objective peer-reviewing (Gökçe Kutsal, 2003). Having a loyal and experienced editor is the driving force in the editing, publishing, and indexing of a journal (Gasparyan, Ayvazyan \& Kitas, 2011). In this sense, a proactive, editorial and managerial board structure with a combination of academics from different schools and universities at national and international scales will potentially improve the quality of journals.

For small-scale journals, editorship can be referred to as a kind of wardership (Crane, 1967), and the narrowness of the editorial board and the range of referees narrows the filtering task of the editor in the review process due to pressure from authors or institutions (Marusic, Mestrović, Petrovecki \& Marusic, 1998). In the case of the bodies of scientific journals, editors, referees, authors, or readers do not take part in clusters separated by sharp lines and boundaries. The author of a journal article is also a referee of another publication and a reader for all articles of the journal (Açan, Özden Pişkin \& Laleli, 2012, p. 4). In this context, it should be noted that the increase in the publication quality of Turkish journals for Geography will only be possible with the common concern, contribution, and awareness of the entire Geography community, not belonging only to the editor, editorial board, and secretariat of the given journal.

When the publication processes and transparency of the journals are checked, it can be said that they are qualitatively good in terms of the arrival date, acceptance date, revision date, referee, and first author information. When the objective and scope of the journals are analyzed, it was determined there are general expressions that do not contain any details, and they are focused on five different categories, including the field of study, education, research methods, focus problem, and specific objective.

When the journals are examined based on the scanned indices, the most indexed journals are Turkish Geographical Review and RIGEO. Based on the criteria for the associate professorship in Turkey, it can be concluded that the most qualified journal in the context of the index is RIGEO, which is scanned in an international field index (ERIC). RIGEO is followed by the International Journal of Geography and Geography Education and Istanbul University Journal of Geography, respectively, which are scanned in the ESCI index. Considering that there must at least two ULAKBIM indexed publication requirements in Turkey's Associate Professorship criteria, five of the seven geography journals bear this requirement. However, Eastern Geography Review is scanned in three different indices but does not meet 
the current requirements based on Turkey's Associate Professorship criteria and scoring system.

In the last area of the study, 56 Geography education academics' bibliometric status in Turkish journals of Geography were analyzed. It was determined that academics of Geography education published in five of the seven journals included in the research; however, they have not published in the Turkish Journal of Geographical Sciences and Eastern Geography Review. Considering that Geographers of pure origin published three publications in Istanbul University Journal of Geography with a professor's title, it can be said that this journal also avoided the field studies of Geography education academics. When the journals' publications are compared according to the academic title, it is determined that the total publications show an increasing trend from research assistants towards professors as a requirement of academic development. In terms of all academic titles, only three journals, namely the International Journal of Geography and Geography Education, Eastern Geography Review, and RIGEO, publish articles from academics with each title. Based on all academic titles, it is noticeable that academics who do not publish in any of the Turkish journals of Geography and publish more than half of their publications in a single journal.

Among the reasons for academics to publish are to respond to an original problem, to spread and share knowledge, to contribute to science, job satisfaction, desire for individual recognition, encouragement or reward, to gain financial profit, to maintain an academic presence (Shokraneh, Ilghami, Masoomi \& Amanollah, 2012). Journals are the meeting place of academics and of academics with society which is a required field in the building of an academic's identity. The power that drives academics to publish takes precedence in defining the identity of an academic (Sağır \& Memiş Sağır, 2019, p.132). Regardless of the rationale, the quality, original, and different expressions should not be ignored in the publications.

The International Journal of Geography and Geography Education are the most commonly published journals for academics of Geography education. In this sense, it is not wrong to also claim that the pulse of publications in Turkish Geography education is beating in this journal. The studies focusing on Geography education are predominantly included in Marmara Geography, and East Geography Journals as these two journals are originated from education faculties. However, given that RIGEO has been publishing for nine years, it can be suggested that it has acquired a special place in this field considering the scanned indices. Given the lack of publications in the Turkish Journal of Geographical Sciences and Aegean Geographical Journal and the scarcity of publications in Istanbul University Journal of Geography and Turkish Geographical Review, it is not wrong to claim that academics who use the keyword of geography education have avoided pure Geography studies.

The results of a bibliometric analysis about the discipline are valuable in terms of the development performance of that field, the focus on a researchers' study, and analysis of the field's strengths and weaknesses (Hotamışlı \& Erem 2014, p. 16). In this study, it was also aimed to determine the policy tendency of the publication processes for scientific Geography-themed journals published in Turkey. It should 
not be ignored that this study is focused on determining the existing situations and reveals quantitative data over numbers rather than quality. Future studies would not be wrong to suggest that the articles published in journals and subjected to a bibliometric analysis on the citation indices will contain clues in qualitative data.

Access Addresses of the Journals Reviewed:

J1. Turkish Journal of Geographical Sciences. https://dergipark.org.tr/tr/pub/aucbd

J2. Eastern Geography Review. https://dergipark.org.tr/tr/pub/ataunidcd

J3. Aegean Geographical Journal. https://dergipark.org.tr/tr/pub/ecd

J4. Istanbul University Journal of Geography. https://dergipark.org.tr/tr/pub/iucografya

J5. International Journal of Geography and Geography Education (IGGE). https://dergipark.org.tr/tr/pub/igge

J6. Review of International Geographical Education (RIGEO). http://rigeo.org/

J7. Turkish Geographical Review. https://dergipark.org.tr/tr/pub/tcd

\section{References}

Açan, N. L., Özden Pişkin, A. K. \& Laleli, Y. (2012). Scientific publication quality: Contributions of editors, authors, reviewers, and readers. Turkish Journal of Biochemistry, 37(1), 1-4.

Al, U. (2008). Scientific publication policy of Turkey: A bibliometric approach based on citation indexes. (Unpublished doctoral thesis). University of Hacettepe, Ankara.

Al, U., Soydal, İ. \& Yalçın, H. (2010). An evaluation of the bibliometric features of bilig. bilig, 55, 1-20.

Borgman, L. C. \& Furner, J. (2002). Scholarly communication and bibliometrics. In B. Cronin (Ed.), Annual Review of Information Science and Technology, 36, 3-72, Medford, NJ: Information Today.

Crane, D. (1967). The gate keepers of science: some factor saffecting the selection of articles of scientific journals. The American Sociologist, 2(4), 195-201.

Diodato, V. \& Smith, F. (1993). Obsolescence of music literature. Journal of the American Society for Information Science and Technology, 44 (2), 101-112.

Erinç, S. (1973). Turkish geography in the 50th anniversary of the Republic. A gift to the 50th anniversary of the Republic, Publication of Istanbul University Faculty of Letters, 113168. İstanbul.

Erinç, S. (1997). “Geography”, science republican era in Turkey, s. 51-55. Ankara, TÜBA.

Gasparyan, A.Y., Ayvazyan, L. \& Kitas, D. G. (2011). Biomedical journal editing: elements of success. Croatian Medical Journal. 52 (3), 423-428.

Gökçe Kutsal, F. Y. (2019). Journals and congresses in the sharing of universal science. JARSS, Anesthesia Journal, 27 (4), 235-44. 
Gökçe Kutsal, Y. (2003). Editor's contributions and responsibilities. In Yllmaz O (Ed), Periodical Publishing in Health Sciences, (p. 67-72). Ankara: TÜBITTAK-ULAKBIM.

Hotamışl, M. \& Erem, I. (2014). Bibliometric analysis of the articles published in the journal of accounting and finance. The Journal of Accounting and Finance, July 1-20.

Karasar, N. (1995). Scientific research method. Ankara: 3A Research Education.

Koçman, A. (1999). Education on geography and its associated problems in universities of Turkey during the republican period. Aegean Geographical Journal, 10, 1-14.

Koehler, W. (2001). Information science as "Little Science": The Implications of a bibliometric analysis of the American Society for Information Science Journal. Scientometrics, 5 (1), 117-132.

Köksoy, M. (1999). International scientific journals and bilig. bilig-8, Winter, 1-11.

Kozak, N. (2000). An overview of the development of the tourism literature in Turkey. DAÜ Journal of Tourism Research, 1 (1), 15-55.

Kozak, N. (2003). Reasons of change in the essential properties of academic journals being published in Turkey: An investigation upon the journals of health social and technical sciences. Bilgi Dünyası, 4 (2), 146-174.

Lawani, S. M. (1981). Bibliometrics: Its theoretical foundations, methods, and applications. International Journal of Libraries and Information Services, 31 (4), 294-315.

Marusic, A.,Mestrović, T., Petrovecki, M. \& Marusic, M. (1998). Peer review in the Croatian Medical Journal from 1992 to 1996. Croatian Medical Journal, 39 (1), 3-9.

Nerur, P. S., Rasheed, A. A. \& Natarajan, V. (2008). The intellectual structure of the strategic management field: an author co-citation analysis. Strategic Management Journal, March, 29 (3), 319 - 336.

Özdemir, H. (2014). About the publications of Turkish Geographical Review in between 1943 and 2013, Turkish Geographical Review, 63, 51-56.

Polat, Z. A., Saraçoğlu, A. \& Duman, H. (2019). Bibliometric analysis of Harita Dergisi. Map Journal, 161, 46-56.

Reitz, M. J. (2014). Dictionary for library and information science. ABC-CLIO Cooperate. Retrieved on 02 November 2019 at https://www.abc-clio.com/ODLIS/odlis_jk.aspx

Rousseau, R. (2002). Journal evaluation: technical and practical issues. Library Trends, 50(2), 419-439.

Sağır, A. \& Memiş Sağır, P. (2019). Transformation of academic production mechanisms with respect to digitalization of information: Journal Publishing from Press to Digital Environment. Journal of Economy Culture and Society, 59, 121-141.

Şahin, C. (2020). Academic journals of geography in Turkey. Türkiye Araştırmaları Literatür Dergisi (TALID), 18 (35), 181-196.

Shokraneh, F., Ilghami, R., Masoomi R. \& Amanollahi, A. (2012). How to select a journal to submit and publish your biomedical paper? Bioimpacts, 2, 61-68.

Stone, J. P., Dunphy, C. D., Marshall, S. S. \& Ogilvie, M. D. (1966). The inquirer: computer approach to analysis. Massachusetts: The MIT 
Tavşancll, E. \& Aslan, A. E. (2001). Content analysis and application examples for verbal, written and other materials. İstanbul: Epsilon.

Tonta, Y. \& Al, U. (2007). Map of Turkey scientific publication: journal publishing in turkey on bibliometric research. Hacettepe University Information and Document Management Department. Retrieved from http://eprints.rclis.org/9473/1/cdmbprojesi-sonuc-raporu-24ocak.pdf

Ulu, S. \& Akdağ, M. (2015). Bibliometric profile of the articles with peer refereeing published in journals: Selçuk Communication Sample. Journal of Selcuk Communication, 9(1): 521.

Ünlü, M. (2020). The contribution of Marmara geography review to the field of geography. Türkiye Araştırmaları Literatür Dergisi (TALID), 18 (35), 325-346.

Yalçın, H. (2010). Bibliometric profile of journal of National Folklore (2007-2009). Journal of National Folklore International Cultural Studies, 22 (85), 205-211.

Yapar Gönenç, A. (2007). The historical development of journalism in Turkey... Connectist: Istanbul University Journal of Communication Sciences, 29, 63-78.

YÖK Academy. (2020). Geography Education. Retrieved from https://akademik.yok.gov.tr/AkademikArama/view/searchResultviewListAuthor.jsp

\section{Biographical Statements}

Çağrı ÖZTÜRK DEMIRBAŞ worked as a social studies teacher in Nevsehir between 2001 and 2002. Öztürk Demirbas has been working at Kırşehir Ahi Evran University Faculty of Education since May 2002 and is currently associate professor. Öztürk was the vice-dean of Kırșehir Ahi Evran University Faculty of Education for two years on 22 May 2015. Öztürk still serves as the representative of associate professors at the Faculty Board and Faculty Administrative Board. She is main focus in geographical education, environmental education, social studies education, concept teaching and use of literature as a teaching tool in geography teaching. 